\title{
A Rare and Serious Complication of Percutaneous Renal Biopsy: Retroperitoneal Hemorrhage
}

\author{
Perkütan Böbrek Biyopsisinin Nadir ve Ciddi Bir Komplikasyonu: Retroperitoneal \\ Hemoraji
}

\author{
(1) Tamer Selen, (1) Hatice Şahin, (1) Ebru Gök Oğuz, (1) Mehmet Deniz Aylı \\ University of Health Sciences, Dıșkapı Yıldırım Beyazıt Training and Research Hospital, Clinic of Nephrology, Ankara, Turkey
}

\begin{abstract}
Renal biopsy is the gold standard diagnostic method in adults with the renal parenchymal disease. Retroperitoneal hemorrhage is one of the rare and most severe complications of percutaneous renal biopsy. The incidence of hemorrhagic complications due to interventional procedures in patients with enoxaparin use is 1.9-6.5\%. Patients undergoing percutaneous renal biopsy under anti-coagulant therapy should be carefully monitored for this potentially fatal complication after a biopsy. In this case report, we presented a 45-year-old female patient who was admitted to our nephrology department for renal biopsy for unexplained proteinuria and hematuria. Because of mitral valve replacement history, a percutaneous renal biopsy was performed under low molecular weight heparin treatment. The follow-up and treatment process of retroperitoneal hemorrhage after the procedure were described.
\end{abstract}

Keywords: Hemorrhage, retroperitoneal area, renal biopsy

\section{öz}

Böbrek biyopsisi renal parenkimal hastalığı olan erișkinlerde altın standart tanı yöntemidir. Retroperitoneal kanama perkütan renal biyopsinin nadir görülen ve en ciddi komplikasyonlarından biridir. Düşük molekül ağırlıklı heparin olan enoksaparin kullanılan hastalarda girișimsel ișlemlere bağlı hemorajik komplikasyonların görülme insidansı \%1,96,5 arasındadır. Anti-koagülan tedavi altında perkütan renal biyopsi yapılan hastalar biyopsi sonrası ölümcül olabilen bu komplikasyon nedeniyle dikkatli izlenmelidir. Bu yazımızda açıklanamayan proteinüri ve hematüri nedeniyle nefroloji servisimize renal biyopsi amacıyla yatırılan 45 yaşında kadın hasta sunulmuștur. Mitral kapak replasman öyküsü nedeniyle hastaya düşük molekül ağırlıklı heparin tedavisi verilerek perkütan renal biyopsi yapılmıștır. Iş̦lem sonrası gelișen retroperitoneal hemorajinin takip ve tedavi süreci anlatılmıştır.

Anahtar Kelimeler: Hemoraji, retroperitoneal alan, renal biyopsi

\section{Introduction}

Renal biopsy is the most important diagnostic and prognostic approach in adults with a renal parenchymal disease (1-3). Indications for renal biopsy include proteinuria, acute renal injury, suspicion of systemic disease associated with renal dysfunction, unexplained renal dysfunction, chronic kidney disease, isolated microscopic hematuria, and graft dysfunction (4). The rare complications of percutaneous renal biopsy are pain, hemorrhage, arteriovenous fistula, Page kidney, perirenal soft tissue infection, and extra-renal organ puncture. In this article, we aimed to present a case with retroperitoneal hemorrhage, which is a rare but severe and fatal complication of renal biopsy.

\section{Case Report}

A 45-year-old female patient was admitted to our nephrology department for renal biopsy due to unexplained renal dysfunction, hematuria, and proteinuria. She had a history of essential hypertension for ten years, hyperlipidemia for five years, and mitral mechanical valve replacement (MVR) surgery. She was on warfarin sodium, atorvastatin, and ramipril. Laboratory results were as follows: hemoglobin (Hgb): $12.3 \mathrm{~g} / \mathrm{dL}$, platelet (PIt): $240 \times 10^{3} / \mu \mathrm{L}$, international normalized ratio (INR): 3.4 , urea: 54 $\mathrm{mg} / \mathrm{dL}$, creatinine $(\mathrm{Cr}): 1.5 \mathrm{mg} / \mathrm{dL}$, +3 protein in complete urinalysis, 4 erythrocytes in urine microscopy, $2.6 \mathrm{~g}$ /day proteinuria on 24 hour urine analysis. Warfarin treatment was discontinued for MVR, and enoxaparin (low molecular weight heparin) was added to the treatment when the INR level was below 2 after close INR follow-up. The patient's enoxaparin treatment was stopped 24 hours before the biopsy. Pre-biopsy laboratory values were as follows: Hgb: $12 \mathrm{~g} / \mathrm{dL}$, Plt: $175 \times 10^{3} / \mu \mathrm{L}$, prothrombin time (PT): $11.7 \mathrm{sec}$, INR: 1.01 and aPTT: $32.1 \mathrm{sec}$. Percutaneous left renal biopsy was performed by interventional radiology. After the biopsy, Hgb values were checked three times at 6-hour intervals, and no decrease 
was detected in Hgb values. The patient's physical examination was normal, and enoxaparin treatment was restarted at 20 hours after the procedure. During the follow-ups, she had a vague left side pain that did not cause rebound tenderness. The patient underwent a urinary system ultrasound examination followed by non-contrast abdominal tomography. There was a 94x98x200 mm hyperdensity, consistent with hematoma, in the para- and perirenal region causing anterolateral displacement of the left kidney and extending to the pelvic region, and that could not be clearly distinguished from the psoas muscle (Figure 1). During laboratory follow-up, the patient's Hgb value decreased to $7 \mathrm{~g} /$ dL. Inotropic treatment was started due to hemodynamic instability, and the patient was transferred to the intensive care unit. She had fever, and sepsis was considered according to qSOFA criteria, and meropenem and teicoplanin were started empirically with the suggestion of infectious diseases clinic. The patient underwent emergency hemodialysis because of uremic symptoms and detected values of urea: $130 \mathrm{mg} / \mathrm{dL}, \mathrm{Cr}: 3.7$ $\mathrm{mg} / \mathrm{dL}, \mathrm{K}: 5.56 \mathrm{mEq} / \mathrm{L}, \mathrm{pH}: 7.0$, bicarbonate: $11 \mathrm{mmol} / \mathrm{L}$. A total of six units of erythrocyte suspensions were administered to the patient in the intensive care unit with the conservative follow-up recommendations of urology and interventional radiology clinics. The patient became hemodynamically stable, and she did not need hemodialysis. She had no active retroperitoneal hemorrhage, and $\mathrm{Hgb}$ value increased to 10 $\mathrm{mg} / \mathrm{dL}$, and $\mathrm{Cr}$ value decreased to $1.21 \mathrm{mg} / \mathrm{dL}$ in the service followup. The patient had regression in hematoma dimensions on control tomography, and she was discharged with warfarin treatment. Informed consent was obtained from the patient.

\section{Discussion}

Percutaneous renal biopsy is the gold standard method used in the diagnosis, treatment planning, and prognosis of renal diseases $(5,6)$. As with any invasive procedure, this procedure has several complications. Retroperitoneal hemorrhage is one of these complications. Retroperitoneal hemorrhage can be seen as a result of trauma or as a complication of vascular lesions, tumors, surgical intervention, and anticoagulant therapy. Retroperitoneal hemorrhage due to enoxaparin is rare, and few cases have been reported so far (7-9). It is essential because of its high mortality.

Enoxaparin has a longer half-life than standard heparin, does not require anti-coagulation monitoring, the risk of heparin-induced

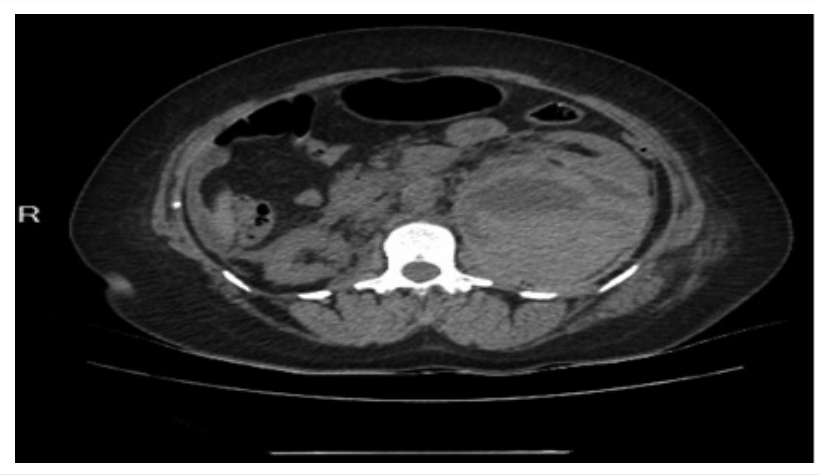

Figure 1. A 94×98×200 $\mathrm{mm}$ hematoma in the left retroperitoneal area, and anterolateral displacement of left kidney secondary to hematoma thrombocytopenia is low, and the cost is less, thus making enoxaparin preferable. Also, hemorrhage complications are reported to be less than standard heparin (10).

In the presence of hypotension, tachycardia, and acute abdominal symptoms during treatment with enoxaparin, anticoagulant therapy should be discontinued immediately, and antidote protamine sulfate should be given. However, if more than 12 hours have elapsed since the hemorrhagic event, the use of protamine sulfate has no meaning (11-14). Hemodynamic monitoring should be performed, coagulation parameters should be monitored, and blood and blood product replacement should be performed. Invasive interventions should be avoided as much as possible. Evaluation should be performed by abdominal tomography, and other life-threatening conditions such as gastrointestinal bleeding and abdominal aortic aneurysm rupture should be ruled out in the differential diagnosis except for the detection of possible bleeding focus (11-15). Surgical intervention or embolization should be considered in patients with worsening of their general condition despite supportive treatment $(14,15)$.

\section{Conclusion}

Hemorrhage risk after invasive intervention should be kept in mind in patients under enoxaparin treatment. In these cases, close hemodynamic follow-up, physical examination, and bleeding control should be kept in mind after the procedure, and anti-coagulant treatment could then be started.

Informed Consent: Informed consent was obtained from the patient.

Peer-review: Externally and internally peer-reviewed.

Author Contributions: Concept - T.S., H.S.; Design - T.S., E.G.O.; Supervision - E.G.O., M.D.A.; Data Collection and/or Processing - T.S., H.Ș.; Analysis and/ or Interpretation - T.S., M.D.A.; Literature Search - T.S., H.Ş.; Writing Manuscript - T.S.; Critical Review - E.G.O., M.D.A.

Conflict of Interest: No conflict of interest was declared by the authors. Financial Disclosure: The authors declared that this study received no financial support.

\section{References}

1. McQuarrie EP, Mackinnon B, Young B, Yeoman L, Stewart G, Fleming S, et al. Scottish renal biopsy registry. Centre variation in incidence, indication and diagnosis of adult native renal biopsy in Scotland. Nephrol Dial Transplant 2009; 24: 1524-8.

2. Fuiano G, Mazza G, Comi N, Caglioti A, De Nicola L, lodice C, et al. Current indications for renal biopsy: a question naire-based survey. Am J Kidney Dis 2000; 35: 448-57.

3. Printza N, Bosdou J, Pantzaki A, Badouraki M, Kollios K, Ghogha CH, et al. Percutaneous ultrasound-guided renal biopsy in children: A singlecentreexperience. Hippokratia 2011; 15: 258-61.

4. Topham PS, Chen Y: RenalBiopsy, in Floege J, Johnson RJ, Feehally J (eds), Comprehensive Clinical Nephrology (4th ed). Elsevier, 2010; 75-82.

5. Pirani CL: Evaluation of kidney biopsy specimens, In Tisher CG, Brenner BM (eds): Renal Pathology: With Clinical and Functional Correlations (2nd ed). Philadelphia, PA: Lippincott, 1994; 85-115. 
6. Önen K: Böbrek hastalıklarının tanısı. Klinik Nefroloji. Cağlar \$ (ed). Ankara: Medial 1986: 57-99.

7. Karabulut Z, Dogan T, Asık M, Ergun T, Lakadamyalı H, Moray G. Enoksaparin ilişkili spontan retroperitoneal hematom. Türkiye Klinikleri Cardiovascular Sciences 2007; 3: 186-9.

8. Akgullu Ç, Yucel E, Aydın Ö, Sensoy B. Enoksaparin Kullanımına Bağlı Spontan Retroperitoniyal Kanama. Turkiye Klinikleri Cardiovascular Sciences 2008; 2: 124-7.

9. Börekci, E. İskemik İnme Sonrası Enoksaparine Bağlı Gelișen Retroperitoneal Kanama. J Contemp Med 2016; 6: 348-51.

10. Malik A, Capling R, Bastani B. Enoxaparin-associated retroperitoneal bleeding in two patients with renal insufficiency. Pharmacotherapy 2005; 25: 769-72.

11. Ernits M, Mohan PS, Fares LG, Hardy H. A retroperitoneal bleedin duced by enoxaparin therapy. Am Surg 2005; 71: 430-3.
12. Bergqvist D, Burmark US, Flordal PA, Frisell J, Hallböök T, Hedberg M, et al. Low molecular weight heparin started before surgery as prophylaxis against deep vein thrombosis: 2500 versus 5000 Xal units in 2070 patients. Br J Surg 1995; 82: 496-501.

13. Kurtoğlu M, Büyükkurt $C D$, Kurtoğlu M, Dural AC, Güloğlu R, Akar U. Politravmatize yoğun bakım hastalarında düșük molekül ağırlıklı heparin ile venöz tromboembolizm proflilaksisi (genișletilmiş seri). Ulus Travma Derg 2003; 9: 37-44.

14. Chan-Tack KM. Fatal spontaneous retroperitoneal hematoma secondary to enoxaparin. South Med J 2003; 96: 58-60

15. Dabney A, Bastani B. Enoxaparin-associated severe retroperitoneal bleeding and abdominal compartmet syndrome: A report of two cases. Intensive Care Med 2001; 27: 1954-7. 